April 1, 2003

Politics and Administration in Council-Manager Government:

Differences between Newly Elected and Senior Council Members

Public Administration Review

May/June 2004

\author{
John Nalbandian \\ Department of Public Administration \\ University of Kansas \\ Nalband@ukans.edu
}

785-864-9096 


\section{Brief Bio}

John Nalbandian teaches in the Department of Public Administration at the University of Kansas. In addition to his academic work, he served on the Lawrence City Commission from 1991-1999, including two one-year terms as the commission's mayor. He specializes in the areas of professionalism in local government and human resources management. 


\title{
Politics and Administration in Council-Manager Government: Differences between Newly Elected and Senior Council Members
}

\begin{abstract}
This study examines differences in attitudes of newly elected and senior incumbents on variables considered the building blocks of the relationship between local elected officials and professional civil service staff: council respect for the city's professional staff; a clear understanding of the roles of council and the staff; and the governing body's commitment towards working as a group and towards consensus. The results show that governing body members who have served for eight or more years show greater respect for staff, greater role understanding, and they value teamwork among their colleagues more than their newly elected counterparts. While there are differences, it appears that the attitudes of the long-term officials change little while in office. They enter office with the building blocks of their own success. These findings are based on a cross sectional and modest longitudinal survey research design, supplemented by indepth interviews.
\end{abstract}




\section{Politics and Administration in Council-Manager Government:}

\section{Differences between Newly Elected and Senior Council Members}

\section{Introduction}

The decisions facing elected officials in today's local governments would prompt the best of us to question the wisdom of running for office. As cities become more politically diverse, the challenges of developing working majorities mount. At the same time that diversity changes the face of politics, the complex technical nature of public problems makes technical expertise and professional management more important. Acting politically to build consensus and a sense of community with policy informed by professional city staff challenges even the most effective local elected officials (Nalbandian 1991, 2000).

While their role has become more complicated and more important, what we know about city councils and their members (Bledsoe 1993; Ehrenhalt 1991; Freeman 1992; Svara 1999a, 1999b) compared to knowledge of Congress (as examples: Fenno 1989, 1991a, 1991b; Loomis 1988) is limited.

This study centers on the question of whether the perspectives on politics and administration that local government elected officials hold change during incumbency. These perspectives are explored in this empirical study of local elected officials in the Kansas City metropolitan area conducted in two phases: in 1999 and in 2001. Data were collected from mailed surveys and in depth interviews. 


\section{Importance of the Study}

For those interested in public administration and professionalism in local government, a study of this nature is important for at least two reasons. First, it adds a longitudinal study of council members and mayors to the ongoing exploration of the relationship between politics and administration at the local level, focusing on councilmanager government. It is unusual in that it provides data collected over time permitting a paired samples statistical examination, and it combines survey data with the results of in depth interviews conducted with a paired group of elected officials in 1999 and 2001. Second, especially in council-manager government, sustained efficient and effective administrative action and service delivery depend in large measure upon a productive relationship between elected officials and professional administrative staff. Knowledge of how local elected officials' view over time this relationship as well as the work of the council itself can contribute knowledge relevant to the effectiveness of council-manager government.

\section{Methodology}

The results reported here come from a two-phase study, spanning 1999-2001 including cross sectional and modest longitudinal aspects. In phase I, the cross sectional phase, I surveyed all local government elected officials in the greater Kansas City area who served in council-manager governments with over 10,000 population. The phase I data analysis compares responses of those who had been elected within six months of the survey $(\mathrm{N}=43)$ with incumbents who had been in office eight or more years $(\mathrm{N}=52)$. Also, I interviewed 16 of the newly elected. Data collected and analyzed in phase I provide the background and research expectations for phase II. 
Phase II took place in 2001, some 18 months after Phase I. In phase II, I resurveyed those newly elected in 1999 and compared paired responses. In addition, I was able to conduct a second interview with nine of those elected in 1999. Thus, phase I permits a cross sectional comparison of the newly elected to incumbents. Phase II actually follows the newly elected for 18 months.

\section{Variables}

\section{Dependent Variables}

The dependent variables in the study related to the relationship between politics and administration in council-manager government are:

- Governing body respect for professional civil service staff

- Governing body understanding of its role and the role of professional civil service staff

- The value of teamwork and consensus on the governing body

These dependent variables had their genesis in pre-survey interviews I conducted with five local elected officials who had been re-elected more than once. Included were two mayors. Three of the interviewees were from Kansas cities and two were from Missouri (greater Kansas City is bi-state). In an open ended format, I interviewed one individually and the others in pairs, and I asked them how they had changed while in office. How did they see things now as opposed to when newly elected? They all acknowledged that changes had occurred, and on the basis of the interviews and my own

experiences, ${ }^{1}$ I developed the survey questions. The questions comparing the three dependent variables result from a factor analysis of the survey results in 1999. These variables are consistent with recent studies of council-manager government (DeSantis 
1998; Fulton 2000; Good 1999; Gurwitt 2000; and Svara, 1999a, 1999b), although those studies differ considerably from this one in their intent.

\section{Independent variable}

The key independent variable in this study is years in office. For the phase I analysis, after exploratory linear regression analyses provided little useful information, I experimented with different categories that years in office, the independent variable, might be divided into, and settled for two:

Less than one year in office $(\mathrm{N}=43)$

Eight or more years in office $(\mathrm{N}=52)$

Less than one year isolates the newly elected officials. The second category includes elected officials who have chosen to run successfully for reelection more than once. Members of this later group are considered the senior elected officials.

\section{Hypotheses}

Hypotheses were developed to compare the perspectives of the newly elected officials with those of the senior elected officials in phase I and for the paired samples tests in phase II.

Hypothesis 1. Longer time in office will result in greater respect for professional city staff.

While it is expected that newly elected would come to office with varying degrees of respect, including uncertainty, for professional city staff, the longer in office the more one becomes exposed to the value of staff work. Few elected officials come to office prepared for the technical complexity of the issues they will face. Few know anything about wastewater collection and treatment, water treatment and distribution, 
telecommunications policy and franchise agreements, finance and budgeting laws and practices, and the list goes on. Professional civil service staff play a crucial role in bringing these issues to the council and preparing information to help council make policy. Few cities provide staff that report to and serve the council directly and where they do those staff almost exclusively deal with constituent services. Those elected officials who do not develop a respect for staff probably will find their time on council frustrating and will not serve several terms.

Hypothesis 2. Longer time in office will increase the understanding that elected officials have of their role and the role of staff.

Again, most newly elected officials, especially those unfamiliar with complex organizations, will approach their role with some degree of uncertainty. In order to be successful, as they mature in office, they are likely to develop an understanding of what they can reasonably expect from each other and from staff. Without developing this understanding, conflict and frustration result.

Hypothesis 3. Longer time in office will increase the value that elected officials accord to consensus and collaboration among the governing body.

Newly elected officials who are successful and are re-elected learn that nothing gets done politically without a majority. The ability to work together is a likely prerequisite for longer terms in office.

Hypothesis 4. There will be a positive association between satisfaction and each of the dependent variables, and the association will be stronger for the senior elected officials.

In many ways, the dependent variables can be seen as factors likely to cause satisfaction. It is hard to imagine a very satisfied work experience for a council member 
in council-manager government who distrusts staff, is unclear about the relationship between council and staff, and does not value teamwork and consensus building. It follows, then, that the longer one serves in office the stronger the relationship will be.

Hypothesis 5. Senior elected officials will be more satisfied than newly elected officials.

Because one must choose to run for reelection, it stands to reason that those who have been reelected several times must enjoy holding political office. Newly elected officials may not know what they are getting into, and several may find the work dissatisfying.

\section{Development and Pre-test of the Survey}

The Kansas City metropolitan area consists of counties in both Kansas and Missouri. The population center is Kansas City, Missouri with about 500,000 residents. The metro area's population numbers about 1.5 million with numerous cities of various sizes. Except for the smallest cities, nearly all in the area are some variation of councilmanager form. Because of this and my interest in elected official-professional civil service staff relations, only local elected officials in cities with a city manager or a similar chief administrative officer were surveyed in summer and early fall 1999. With spring 1999 local elections, the elected officials in this study had a few months of experience to draw upon in responding to the questionnaire and initial interview.

I conducted a pre-test of the instrument that totaled 53 questions by mailing the questionnaire to a random sample of 100 of the metro area's local elected officials in the Fall of 1998. At that point, I had not decided to eliminate non-council manager cities or the smallest cities. With elections scheduled for April 1999, none of the newly elected officials tested the following summer/fall were included in the pre-test. Some of the 
incumbents may have been. Most variables were measured with Likert scale items, 1-5, (strongly agree, agree, neutral, disagree, strongly disagree).

Twenty-six of the pre-test surveys were returned and were analyzed. In the cover letter I asked respondents to complete the questionnaire and to note questions that were unclear. On the basis of some elementary analysis, including tests of association, I eliminated some of the questions and rewrote a few of the others.

\section{Survey}

In mid-July 1999, utilizing a list the Mid-America Regional Council (the Kansas City area Council of Governments) maintains, I mailed the survey to all local elected officials in the metropolitan area in cities that had a chief administrative officer. The surveys were mailed and returned within six months of the election.

Three hundred and twenty surveys were mailed to local elected officials in 44 jurisdictions, with a follow-up postcard, and a second mailing of the survey to those who had not responded within four weeks of the initial mailing. The final response rate was 59 percent $(\mathrm{N}=190)$, which included 43 newly elected officials and 52 senior elected officials. There is no appreciable statistical difference in the profile of those responding to the first and second mailings.

Utilizing a factor analysis ${ }^{2}$ with an eigenvalue cutoff point of one, five factors were revealed explaining 63 percent of the variance. On the basis of the factor analysis three variables relating to politics and administration were isolated and organized into scales. Questions loading higher than .5 on the factor were included. A scale score was determined by averaging responses to the appropriate questions. ${ }^{3}$ The resultant variables were subject to data analysis. 
- Respect for staff (4 questions)

- Role understanding between council and staff (2 questions)

- Collaboration among governing body members (3 questions)

The questions comprising the scale for each variable are presented in the appendix.

\section{Profile of Respondents}

Table one shows that respondents in this study are fairly similar. They are mostly male, middle aged, politically middle of the road to conservative, and well educated. Slightly more are from Missouri than Kansas, most are elected by district and run on a non-partisan ballot. They are part-time council members who have full-time jobs divided among small and large organizations. The majority is self-employed. Except for those from Kansas City, Missouri, the majority comes from small to medium sized suburban communities in a metropolitan area that is growing rapidly.

\section{[Table 1 about here]}

The profile of the newly elected does not appear to differ consistently from senior incumbents. Table one shows that the only significant differences appear in age (46-56) and a related variable, the number employed outside the council. As expected, the senior incumbents are older and many are retired. When removing Kansas City, Missouri from the numbers, the population of the cities the new and senior incumbents serve in is roughly similar. An observable difference is seen in aspirations for higher office with the newly elected having more aspirations or being more uncertain than incumbents who 
more clearly have decided that local government is where their political careers will end. There is no way of knowing if the senior incumbents would have expressed similar aspirations for higher office when newly elected.

\section{Data Analysis, Phase I}

To test the first three hypotheses t-tests were performed with years in office as the independent variable and each of the politics and administration variables as dependent. The results are shown in Table 2 .

[Table 2 about here]

For the respondents as a whole, the mean of 2.1(not shown in the Table; 1 is high and five is low on the Likert scale) on "respect for staff" indicates mostly agreement with the way staff conducts its business. Understanding of the council's role and staff's role falls nearly in the middle of the five point scale $(\mathrm{M}=2.37, \mathrm{SD}=.82)$, indicating that local elected officials are not very clear on their role nor that of staff. Respondents regard "teamwork on the governing body" as very important. The mean here is 1.6.

Turning now to the differences that can be ascribed to years in office, the general direction of the differences on all three of the variables is in the direction hypothesized, even though only the difference on "respect for staff" reaches a statistically significant level. Long term elected officials compared to the newly elected have more respect for professional staff, more comprehension of their role and the role of staff, and they value teamwork and consensus on the governing body. Thus, the thrust of the first three 
hypotheses is in an expected direction, but the lack of statistical significance warrants caution. $^{4}$

\section{Job Satisfaction}

Before concluding the analysis in Phase I, I wanted to know if there was a relationship between level of "job satisfaction" and the dependent variables as well as years on the job. Table 3 shows the statistical correlations between satisfaction and the dependent variables. The results show that the most satisfied elected officials are those who have the most respect for staff, understand the two roles, and value teamwork on the governing body, even though the relationships are modest, they are statistically significant and consistent with hypothesis 4 .

[Table 3 about here]

Comparing the association of job satisfaction with respect for staff, role understand, and teamwork on the council for the newly elected and senior incumbents, one sees in Table 4 that in general the politics-administration dependent variables are more closely associated with the satisfaction of the newly elected than their senior counterparts on the two factors that directly relate to council-staff relations. Of the factors that are associated with job satisfaction for senior incumbents, relationships among the council are the strongest. This result in inconsistent with hypothesis 4 which anticipated that satisfaction of senior elected officials would be more closely associated with the dependent variables. 
[Table 4 about here]

It is surprising to me that the associations are not stronger because in councilmanager government so much success in a governing body member's work is tied to a positive relationship with staff as well as effective relationships among the council. The implication of the results is that other factors, not measured in this survey, contribute to the council members' satisfaction, especially as the newly elected officials begin to mature in office. These might include variables like degree of influence, level of accomplishment, prestige, involvement in intergovernmental relations, and recognition in the community, among others.

Table 5 shows that while all elected officials in the survey are quite satisfied with their job, the most senior are the most satisfied, consistent with hypothesis 5. This makes intuitive sense. Why would a governing body member run for reelection if not satisfied with the work? In addition, the table shows that while newly elected officials are quite satisfied on average, there is a considerable amount of variation (SD .99) in their responses in contrast to those holding office for more than eight years (SD .61).

[Table 5 about here]

\section{Summary of Phase I Analysis}

Regardless of years in office, there is a high level of agreement among respondents that teamwork and consensus building among the council are important. There is less agreement on the importance of respect for staff and least agreement is seen 
on extent to which governing body members express understanding of the council and professional staff's role with the response mean falling near the middle of the 1-5 Likert scale.

More than the newly elected, senior elected officials are respectful of staff, understand role differences between staff and council, and endorse consensus building and teamwork on the council. These results, while not statistically significant uniformly, do point in the direction hypothesized.

Regarding the elected officials satisfaction with their work, senior officials are more satisfied than the less experienced, and their level of satisfaction is associated with respect for staff, role understanding, and teamwork and consensus building among the council. But surprisingly, the associations are generally stronger for the newly elected. When both groups are considered together, satisfaction and the dependent variables are associated at statistically significant levels.

Having completed analyses of the cross sectional data, one is left to question whether the observed differences between the newly elected and their senior incumbent counterparts are the product of learning in office. Or, do the newly elected and those serving eight or more years represent significantly different populations? The profile of the respondents portrayed in Table 1 would suggest that they are not different enough to discount the conclusion that with time local elected officials do learn about relationships with themselves and staff that lead to productive and satisfying work. A longitudinal design would test this conclusion about learning directly. Phase II of the study, consisting of the survey in 1999 repeated in 2001 for paired samples of the newly elected including in depth interviews at both points, provides a step in that direction. We now 
turn to that analysis hypothesizing change and learning in the directions anticipated from the Phase I analyses. That is, after nearly two years in office, the newly elected will develop more respect for staff, more understanding of role expectations for themselves

and staff, and will value council teamwork more. In addition, their level of satisfaction will increase.

\section{Phase II Data Analysis}

In Phase II, 43 questionnaires were mailed and 23 (66 percent) were returned after a reminder postcard and a second mailing of the survey. Table 6 shows the results of the paired sample t-tests. The task here is to search for evidence of change in the direction expected from the Phase I analysis. If the evidence is found, it could be argued that as elected officials serve in office, part of their learning includes the development of positive attitudes about the aspects of politics and administration we are focusing on in this study.

[Table 6 about here]

The results show little change in the respect and role understanding variables. There is a statistically significant change in the council teamwork variable, but the direction of change is opposite from what is anticipated. Even though there is a high absolute value placed on teamwork and consensus on the council, the importance is less in 2001 than it was in 1999. Considering all three dependent variables, these results are inconsistent with the trend seen in Phase I where time in office appears to produce modest change in the predicted fashion. 
With regard to satisfaction, the results seen in Table 7 show there are virtually no differences between these first term elected officials when surveyed in 1999 and 2001. In both cases, satisfaction is quite high. A trend towards the even higher level of satisfaction seen in senior incumbent politicians is not evident in this two-year comparison.

[Table 7 about here]

\section{Phase I and II Comparison Summary and Conclusions}

I expected the Phase II longitudinal analysis to confirm the direction of change revealed from the cross sectional, Phase I analyses of the newly elected and senior incumbent elected officials. In other words, I was expecting to see evidence that the changes between the attitudes of the newly elected and senior incumbents in Phase I would begin to be revealed in the longitudinal analysis that Phase II of the research provides. That evidence did not materialize.

It appears that what we see in the attitudes of the senior incumbents is not the result of a transformation of the newly elected. The alternative hypothesis is that those who enter office with the attitudes exhibited by the senior incumbents are those who survive in office. In other words, newly elected officials learn about politics and administration what they are predisposed to learn. This hypothesis is akin to the survival of the fittest. Those who enter office with predispositions towards the attitudes exhibited by the senior incumbents surveyed in Phase I of this study are those who successfully continue to seek office. 


\section{Interview Results}

Our last task is to examine the in-depth interviews of the paired samples. I was able to interview 16 of the newly elected in 1999 and to interview nine of them again in 2001. Examination of the interview text provides evidence that the attitudes that the newly elected enter office with are those that they maintain while in office; those attitudes are refined not substantially altered while in office.

I compared the nine interviews looking for changes in areas related to the council staff relationship and attitudes about the council itself, paralleling the dependent variables in the study. I asked open-ended questions directly connected to each variable and immediately prior to the second interview, I sent the interviewee the text of what he/she said in 1999. I conducted the interviews myself at the elected official's home, office, or city hall. Interviews lasted anywhere from 45 minutes to 1.5 hours.

The findings are summarized in Table 8. Quadrant I represents positive change. In the case of the particular council member who fell partially into this category, it was his attitude towards the city's professional staff that had changed. The 3.5 governing body members in quadrant II held positive attitudes in 1999, which were seen in 2001 as well. The 3.5 in quadrant III changed towards the negative—-ess respect for staff or more criticism of how the council operates. Finally, in quadrant IV, 1.5 council members held attitudes that started negative and remained that way.

[Table 8 about here] 
In 4 cases there were changes, and in 5 cases there were no changes. Where change did occur, it was not in the direction predicted from an examination of the survey data where senior incumbents showed more positive attitudes towards staff and council when compared to the newly elected. The survey data would have predicted more council members falling into quadrant I, the least populated category. So, not only was there less change than one might anticipate based on the survey results, the change that is seen occurs in an unexpected direction.

To provide examples of the ways that elected officials' thinking about their initial two years in office with regard to relationships with staff and other governing body members changes in some cases and remains the same in others, I will provide a 1999 and 2001 illustration from each quadrant.

Council member I was no stranger to politics when he took office in 1999 in this large urban city. Earlier he had worked as an aide to a council member and then to a mayor. He holds an at-large seat on a council that consists both of at-large and district offices. An African-American, he sees himself as bringing various groups together, especially around issues that have racial overtones. Being familiar with politics, it is not surprising that he expressed considerable satisfaction at being a council member.

In our first interview, when asked to give an example of a satisfying experience, he told me a story about an individual constituent who he was able to help, reinforcing for me his people to people view of politics. When asked about trusting the city's professional staff, in 1999 he said, "For the most part. They've never misled me in any way, shape, or form. Basically, after being there for a while, you [the council member] can understand where the bodies are buried and how things work." This characterization 
of staff is positive, but hardly enthusiastic. It suggests his sensitivity to the vulnerability that council members have in their relationship with professional city staff.

In 2001, the characterization undergoes positive change. In fact, council member I became more critical of the council than in 1999 (thus the .5 rating in quadrant I and .5 in quadrant II). Similar to the question I posed in 1999, I asked him how his respect for staff had been affected since his election. He answered, "Actually, for me it's gone up...These people go about moving forward our directives. They cannot create policy. We're the policymakers. To a large extent, if they fail, it's a failure on our part."

He continued by identifying one of council's roles as providing professional city staff with the tools needed for them to be productive. When I asked him to give me an example of what he meant by tools, he added: "A core vision. A clear sense of direction first and foremost. Everything flows from that." And, when asked directly about his relationship with staff, he said, "I think you grow into the roles. I think they're [professional city staff] learning me. I'm learning them. We're learning how to work together to the extent that it's effective for the process of work."

Council member I's characterization of the relationship in 2001 is more positive than in 1999; it seems enriched by his experience. It reveals a more fully developed understanding of the kind of council-staff relationship required to effectively fulfill the council's member's policymaking role in addition to the constituent services role.

Council members I and II come from the same jurisdiction. Council member II is elected by district. Before his election, he had served on an important city advisory board that familiarized him with the city's entire capital budget and land-use planning process. He is a very thoughtful and independent thinker, and is considered by some a possible 
future candidate for mayor. In his words, "I come from the business community, so I tend to be a fairly reasonable person that tends to base decisions on logic and fact. And sometimes facts and logic don't necessarily matter when you're [citizen advocates] passionately against something."

When asked in 1999 what his initial experiences had been like working with the council and mayor, he said: “It's been mixed. But overall I'd say it's been really positive. We have a very good working relationship here. People do things that surprise you, absolutely, and are politics played? Absolutely. I think one of the things we're finding is that we have, I think a little bit younger council than we've had in the past. Those of us that are younger in age have some, and just some generational differences between those that have come before us and the way we view service and the way we view politics. We tend to be a little bit more professional and a lot less cutting deals behind the scenes, rather than just working things out in a public way." In 2001, his views changed in a negative direction. He characterized the relationship between the mayor and council in the following terms:

My expectations [in 1999] would have been that we [mayor and council] would've communicated much more frequently. There's no communication from the mayor's office at this level [with the council] for the most part. There is a fair amount of communication on this floor amongst the council people. Even still, you have to work on your stuff and your ideas somewhat by yourself.

People are looking to that particular individual [the mayor] and saying, you're our leader, therefore lead. And if that doesn't happen, then it boils down to what you [the interviewer] said, 12 independent people [the council members] doing a hodgepodge of 
work. Some of it good and some of it fine, but it's not necessarily this cohesive, comprehensive, methodical, strategic approach to city hall.

Council member II's experience is limited, of course, to some two years at the time of his second interview. And in fairness to the mayor, based on my interviews with her, there are two sides to council member II's story. And clearly, one cannot assume that attitudes changed over two years would not change again in another direction. But, council member II sees himself as logical and rational, and the passion of politics that leads to challenges in communication among political actors is probably unsettling, or at most, something to be tolerated. It is quite plausible that his negative experiences are, in part, the product of the expectations and style he brought to the council.

Council member III is from a small, free-standing city just north of the Kansas City metropolitan area. He is retired military, has worked in a large manufacturing firm in labor relations, and was a homeowner's association president in a small development in Colorado before retiring to the Kansas City area. He finds his work as an elected official very satisfying and the relationship with staff exemplary: “Oh, just great. They’re good employees. They're very, very easy to work with. Anything I've asked for, in terms of reports, history, or information of any kind, they just drop what they're doing and get that for you. There's many times before a council meeting, I'll need some information on something. I just either call city hall or stop by, and they've been outstanding to work with. No problems, whatsoever." His comments in 2001 are nearly indistinguishable from those he made earlier. 
We have an excellent city staff, a city manager that's an outstanding young man, and he keeps us posted on things that are going on. We have very few labor problems or anything like that, employee problems.

Anything that the elected officials need in terms of information, our city administrator is usually on the phone calling us before we call him. Keeps us very well informed...If there's some question about an item coming up, I'll call Mike, and he'll tell me what it is.

Council member III's response was most typical, whether positive or negative. Not much change; predispositions brought to the work in 1999 appear to be reinforced and expressed again in 2001 .

The last illustration comes from quadrant IV. This council member was very involved in school matters and citizen advocacy relating to schools prior to coming to the city council. She is a high energy, hard-working council member who, in her words, represents a new guard. She said she had no idea what she was getting into when she ran, but she was tired of the council bickering and fighting. "The more I sat there, and the more I listened, I knew it didn't have to be that way...And, I decided that I was going to try and make a difference."

When I asked her in 1999 about her expectations of the relationships between council and professional city staff, she said: "I really didn't have any expectations there. My personal opinion on this situation is there needs to be a lot of reworking on this...There's no accountability; there's no detailed job descriptions, responsibilities, performance evaluations, critique of long-range plans. I mean, there's nothing!” 
In 2001, while her opinion is not nearly as harsh, it portrays an arms length relationship. It is hard to envision council member IV describing the council-staff relationship as a partnership. When asked how she sees staff after nearly two years in office, she said: "For the most part I think it's all stayed the same even with one department head that I still at that time thought should be fired and still at this time think should be fired because he's very incompetent. But I think that all of them...I know they know me as the one that you send out your finance meeting report, even though I'm not on the committee, I'll probably read it and send them questions.”

Then, in a passage that reveals her style and predispositions as much as council member II revealed his, she says: "I think I trust them for the most part. I mean as far as all out trust and not checking what they send me or showing up and just voting on something with just their word and piece of paper in front of me without questioning or asking, no I wouldn't do it. And that's probably just me. I do that basically in everything. I'm kind of, I wouldn't say distrustful, but I'm hesitant at just taking it as word of gold and going with it."

Even though there are only 18 interviews, nine people interviewed twice 18-20 months apart, the results are consistent with the test-retest survey results seen in Phase II. By and large, there is little change in these elected officials during there initial term in office. And, where there is change, it is towards the negative either in terms of council's relationship with staff or in how the council views itself.

\section{Summary and Conclusions}


This study employs both a cross sectional and longitudinal survey design. In addition, it incorporates interviews conducted in a timeframe corresponding with collection of the longitudinal data.

We started with the question of how local elected officials' attitudes toward professional city staff and towards a team oriented view of the council change over time. The survey results comparing the newly elected with senior incumbents show differences. Even though they do not uniformly reach statistical significance, all point in the direction hypothesized. More than the newly elected, senior elected officials show more respect for professional city staff, more understanding of their role as council members and the role of the staff, and are more likely to see council as a working body rather than as an aggregate of individuals.

The test-retest of the newly elected in 1999 and again in 2001 was designed to see if the differences between the newly elected and senior incumbents could be anticipated. They could not. Furthermore, interviews conducted in 1999 and again in 2001 showed little change in attitudes, and where there were changes, they were in the opposite direction than anticipated.

I conclude that when compared with the newly elected, senior incumbents are probably different in their attitudes about staff and council. But these differences are not likely to be attributable to change through experience on the council. While there will be isolated cases of dramatic change, I believe that senior incumbents adhere to the same attitudes they entered with; the attitudes were reinforced, tweaked, affected at the margins throughout the years. Those that are predisposed upon initial election to be respectful of 
staff, to understand the differences in staff and council roles, and to see council as a teamoriented working group, are more likely to be successful in re-election.

If these conclusions are accurate, they point back to the fundamental notion that a productive partnership between elected and appointed officials and among the elected officials themselves in council-manager government, are the building blocks of long term service as local government elected officials. Disturbing, however, for those who see the council-city staff relationship in partnership terms, are results that show all officials in this study more or less unclear about the roles of council and staff. This result is wholly consistent with Svara's (1999a, 1999b) recent research showing more ambiguity about roles in big cities. Taken together, these studies point to an important area of concern.

Finally, what is not clear here, and what presents itself as a challenge for future research, is why the satisfaction of senior incumbents, while greater than their newly elected counterparts, is not more closely tied with these building blocks to an effective political and administrative relationship. 
Table 1. Profile of Respondents

\begin{tabular}{|l|l|l|l|}
\hline & Mean & Less than & More than \\
& & One year & Eight Years \\
\hline Number of respondents & & 43 & 52 \\
\hline Age & 50.76 & 46.7 & 56.5 \\
\hline Gender (Male/Female) & & $29 / 14$ & $37 / 15$ \\
\hline State (KS/MO) & & $20 / 23$ & $23 / 29$ \\
\hline Population & 54,786 & 82,697 & 29,689 \\
\hline Pop. (without KC, MO)* & 32,567 & 23,135 & 29,689 \\
\hline At-large/District & & $17 / 25$ & $21 / 31$ \\
\hline Party Affiliation (yes/no) & & $2 / 40$ & $4 / 48$ \\
\hline Educational Level (high school/ & & $5 / 15$ & $7 / 18$ \\
\hline Graduate education) & & & \\
\hline Full-time/Part-time & & $12 / 9 / 21$ & $8 / 30 / 14$ \\
\hline Employed outside council (yes/no) & & $38 / 5$ & $35 / 16$ \\
\hline Size of outside employer (less than 50 & & $22 / 17$ & $21 / 16$ \\
\hline employees/over 100 employees) & & & \\
\hline Self-employed (yes/no) & & & \\
\hline Political Aspirations (yes/no/maybe) & & $5 / 25 / 18$ \\
\hline Ideology (liberal/middle/conservative) & & & \\
\hline
\end{tabular}


*Kansas City, Missouri has nearly four times the population of the second most populous city. 
Table 2. T-test. Years In Office and Dependent Variables

\begin{tabular}{|c|c|c|c|c|c|c|c|}
\hline & $\begin{array}{l}\text { Years } \\
\text { In Office }\end{array}$ & $\mathbf{N}$ & Mean & SD & $\begin{array}{l}\text { Degrees of } \\
\text { Freedom }\end{array}$ & $\begin{array}{l}\text { T } \\
\text { Value }\end{array}$ & Sig. \\
\hline \multirow[t]{2}{*}{ Respect for staff } & Less than 1 & 43 & 2.28 & .88 & \multirow[t]{2}{*}{75} & \multirow[t]{2}{*}{2.17} & \multirow[t]{2}{*}{.039} \\
\hline & 8 or more & 52 & 1.94 & .65 & & & \\
\hline \multirow[t]{2}{*}{ Role understanding } & Less than 1 & 43 & 2.50 & .96 & 93 & .94 & .34 \\
\hline & 8 or more & 52 & 2.32 & .91 & & & \\
\hline \multirow[t]{2}{*}{ Council Teamwork } & Less than 1 & 43 & 1.66 & .57 & 92 & 1.50 & .14 \\
\hline & 8 or more & 51 & 1.50 & .43 & & & \\
\hline
\end{tabular}


Table 3. Pearson Correlations Job Satisfaction and Dependent Variables

\begin{tabular}{|l|l|l|l|l|}
\hline \multirow{5}{*}{ Satisfaction } & & Respect & Role & Council \\
\cline { 2 - 5 } & Pearson Correlation & .395 & .452 & Teamwork \\
& Sig. (2-tailed) & .000 & .000 & .318 \\
& $\mathrm{~N}$ & 95 & 95 & 902 \\
\hline
\end{tabular}


Table 4. Pearson Correlations Job Satisfaction and Dependent Variables by Years in Office

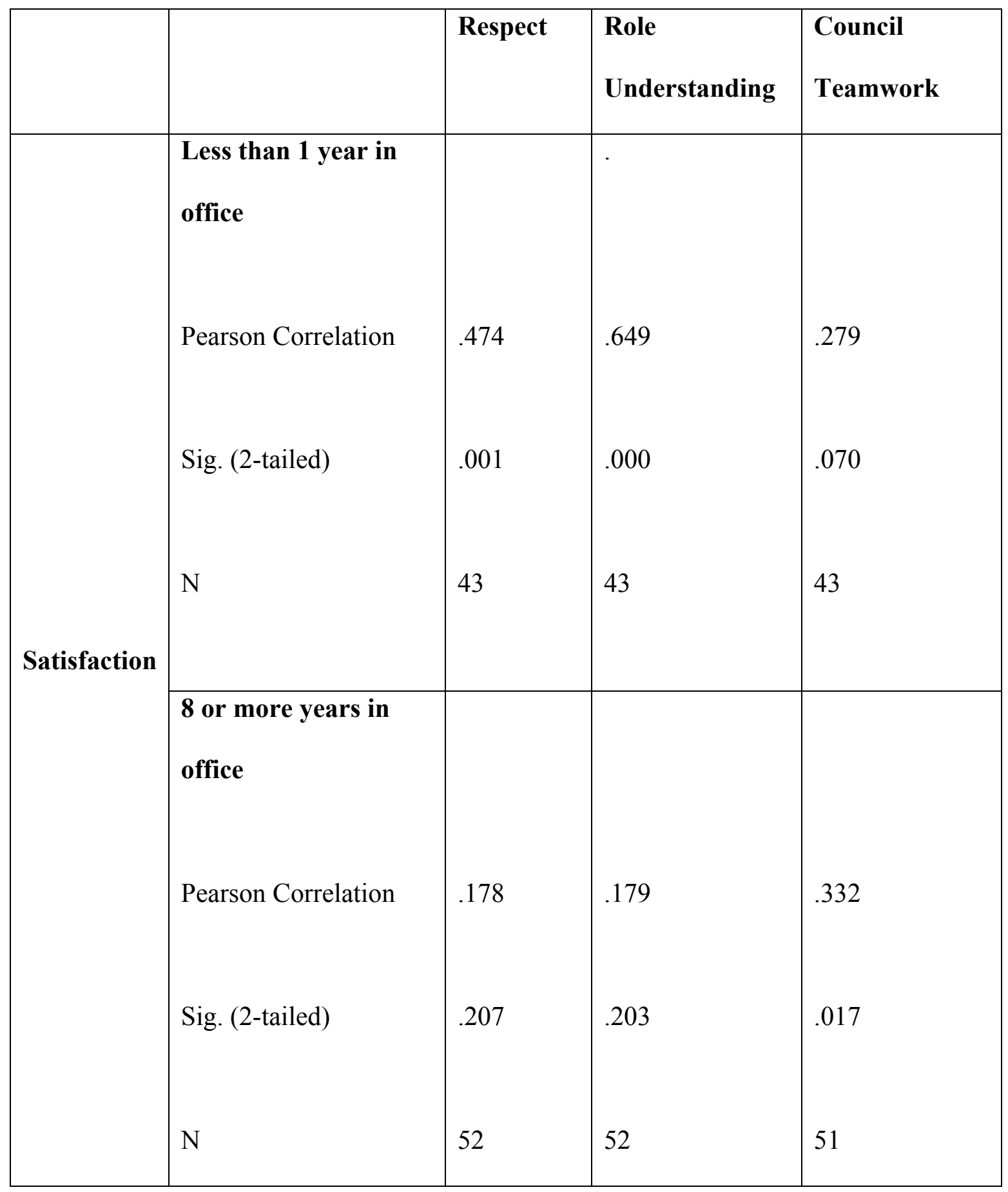


Table 5. T-test Years in Office and Job Satisfaction

\begin{tabular}{|l|l|l|l|l|l|l|l|}
\hline & Years in Office & $\mathbf{N}$ & Mean & SD & Degrees of & $\mathbf{T}$ & Sig. \\
\hline Satisfaction & Less than 1 year & 43 & 1.86 & .99 & 93 & 1.94 & .055 \\
& & & & & & & \\
\cline { 2 - 5 } & 8 or more & 52 & 1.54 & .61 & & & \\
\hline
\end{tabular}


Table 6. T-Tests for Paired Samples 1999 and 2001Dependent Variables

\begin{tabular}{|c|c|c|c|c|c|}
\hline & Mean & $\mathbf{N}$ & Std. Deviation & $\mathbf{T}$ & Sig. \\
\hline 1999 Respect for Staff & 2.26 & 23 & .74 & \multirow{2}{*}{.84} & \multirow{2}{*}{.41} \\
\hline 2001 Respect for Staff & 2.15 & 23 & .53 & & \\
\hline 1999 Role & 2.56 & 23 & .94 & \multirow{4}{*}{.21} & \multirow{4}{*}{.83} \\
\hline Understanding & & & & & \\
\hline 2001 Role & 2.52 & 23 & .71 & & \\
\hline Understanding & & & & & \\
\hline 1999 Teamwork & 1.59 & 22 & .54 & \multirow{2}{*}{2.03} & \multirow{2}{*}{.05} \\
\hline 2001 Teamwork & 1.80 & 22 & .66 & & \\
\hline
\end{tabular}


Table 7. 1999-2001 Paired Sample T-test Satisfaction

\begin{tabular}{|l|l|l|l|l|l|}
\hline & Mean & $\mathbf{N}$ & Std. Deviation & $\mathbf{T}$ & Significance \\
\cline { 1 - 5 } 1999 I am very satisfied & 1.70 & 23 & .87 & \multirow{2}{*}{-214} & .83 \\
\cline { 1 - 5 } 2001 I am very satisfied & 1.74 & 23 & .75 & & \\
\hline
\end{tabular}


Table 8. Changes in Dependent Variables, 1999-2001 Interviews*

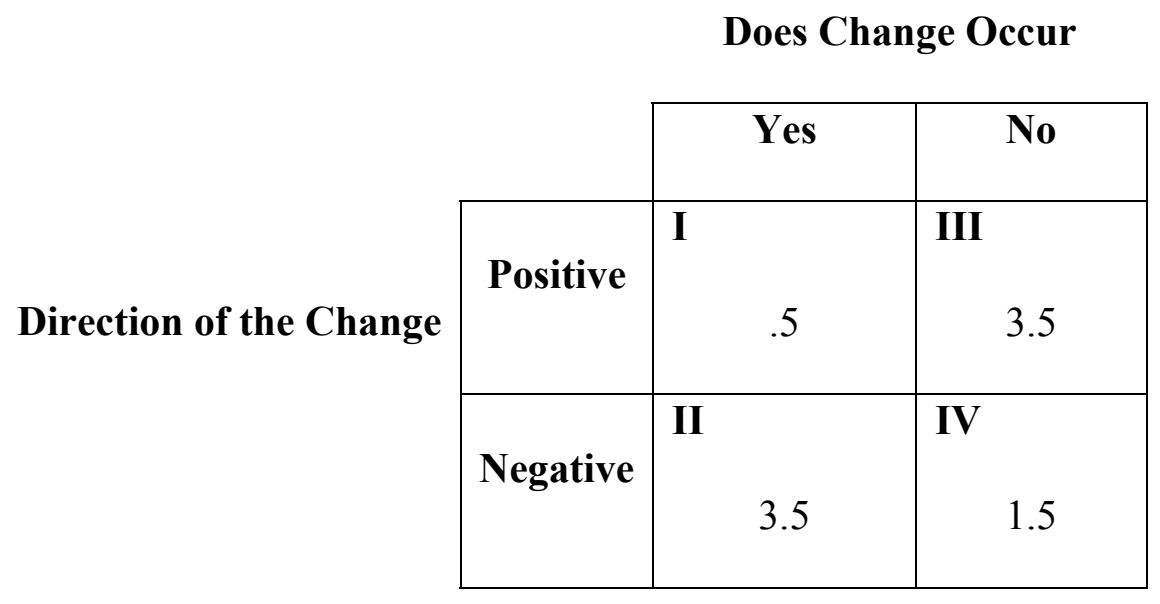

*Nine elected officials were interviewed twice. Each council member could have changed either in attitude towards the city's professional staff or towards the council. Some changed in one area and not the other, thus the .5 numbers. 


\section{Appendix}

\section{Dependent Variables}

\section{Respect for staff}

- The staff understands its role very well. (q. 16)

- The staff understands the governing body's role very well. (q. 15)

- I think the staff does excellent work. (q. 14)

- I agree with the way staff approaches problems (q. 12)

\section{Role understanding}

- The governing body understands staff's role very well. (q. 19)

- The governing body understands its own role very well (q. 20)

\section{Teamwork and consensus on the governing body}

- My success as a member of the governing body depends upon my ability to work as a member of a team. (q. 10)

- I think that consensus building and collaboration are the keys to an effective governing body. (q. 9).

- I think that the governing body needs long-term goals in order to function effectively. (q. 11) 


\section{Acknowledgement}

I would like to thank my colleague, George Frederickson, for his helpful comments on an earlier version of this article. 


\section{Notes}

1. I served as a local elected politician in Lawrence, Kansas from 1991-1999-two four-year terms, including two one-year terms as the council's mayor.

2. SPSS was utilized. Extraction method: Principal Component Analysis; Rotation Method: Varimax with Kaiser Normalization

3. Factor scores were considered but rejected in favor of scale scores that had common intuitive meaning.

4. I went beyond the expressed hypotheses and utilized several other variables in a series of statistical tests to determine which might help explain more variance in the dependent variables. No consistent explanations are apparent, and this exploratory vein is not reported here. 


\section{Reference List}

Bledsoe, Timothy. 1993. Careers in City Politics: The Case for Urban Democracy. Pittsburgh: University of Pittsburgh Press.

DeSantis, Victor. July 1998. Council-Manager Relations at the Crossroads. Public Management 80(7): 10-15.

DeSantis, Victor and Robin Leal. September 1998. The Manager's Role at Century's End. Public Management 80(9): 10-16.

Erhenhalt, Alan. 1991. The United States of Ambition: Politicians, Power, and the Pursuit of Office. New York: Random House.

Fenno, Richard F., Jr. 1989. Learning to Legislate: The Senate Education of Arlen Specter. Washington, DC: Congressional Quarterly.

Fenno, Richard F., Jr. 1991a. The Making of a Senator: Dan Quayle. Washington, DC: Congressional Quarterly.

Fenno, Richard F., Jr. 1991b. Pete Domenici and the Regan Budget. Washington, DC: Congressional Quarterly.

Gurwitt, Rob. January 2000. Playing Duopoly Governing 13(4): 16-20.

Loomis, Burdett. 1988. The New American Politician. New York: Basic Books, 1988.

Nalbandian, John. 2000. The City Manager as Political Leader. Public Management 82(3): 7-14.

Nalbandian, John. 1991. Professionalism in Local Government. San Francisco: Jossey Bass. 
Svara, James, H. 1999a. Conflict and Cooperation in Elected-Administrative

Relationships in Large Council-Manager Cities. State and Local Government Review 37(3): 173-189.

Svara, James H. 1999b. The Shifting Boundary between Elected Officials and City Managers in Large Council-Manager Cities. Public Administration Review 59(6): 44-53. 